\title{
PARTISIPASI ANGGOTA KELOMPOK TANI DALAM MENUNJANG EFEKTIVITAS GAPOKTAN PADA KEGIATAN PENGUATAN LEMBAGA DISTRIBUSI PANGAN MASYARAKAT DI KABUPATEN BOGOR
}

\author{
Yudhi Harsatriadi Sandyatma \\ Badan Ketahanan Pangan, Kementerian Pertanian \\ Email: yudhi_bbkp@yahoo.com \\ Sunarru Samsi Hariadi \\ Program Studi Penyuluhan dan Komunikasi Pembangunan \\ Sekolah Pascasarjana Universitas Gadjah Mada \\ Email: sunarru_sh@yahoo.com
}

\begin{abstract}
The study aims at evaluating participation of the Farmer Group Association (Gapoktan) members and factors affecting their participation in the food community Distribution institution program (PenguatanLDPM). It also examines the impact of the members' participation on the effectivesness of Gapoktan involvement in the program. The study was conducted in Bogor, West Java. It used mixed methods: qualitative and quantitative. Sampling consisted of 91 respondents and 15 informants. The sampling techniques used were proportionate stratified random sampling and purposive techniques, respectively. The results showed that the level of members' participation in the program was low. Factors that significantly affected their participation included age, income, motivation, and intensity of socialization the activity received. In terms of target achievement, members' participation has a positive impact on the effectiveness of the association.
\end{abstract}

Keywords: Participation, Farmers Group Association, Effectiveness, the Food Community Distribution Institution Program

\begin{abstract}
ABSTRAK
Penelitian ini bertujuan untuk mengetahui tingkat partisipasi anggota Gapoktan penerima Kegiatan PenguatanLDPM, faktor-faktor yang mempengaruhi partisipasi anggota Gapoktan dalam Kegiatan Penguatan-LDPM, dan pengaruh partisipasi anggota Gapoktan terhadap efektivitas Gapoktan pada Kegiatan Penguatan-LDPM. Penelitian dilakukan di Kabupaten Bogor, Jawa Barat dengan menggunakan metode penelitian kombinasi kualitatif dan kuantitatif (mixed methods) dengan jumlah sampel sebanyak 91 responden dengan teknik proportionate stratified random sampling dan 15 informan secara purposive. Hasil penelitian menunjukkan bahwa tingkat partisipasi anggota Gapoktan pada Kegiatan Penguatan-LDPM adalah rendah. Faktor-faktor yang signifikan berpengaruh terhadap partisipasi anggota Gapoktan pada Kegiatan Penguatan-LDPM adalah usia, pendapatan, motivasi, dan intensitas menerima sosialisasi kegiatan. Terkait dengan efektivitas Gapoktan yang dilihat dari proses mencapai tujuan, partisipasi anggota Gapoktan pada Kegiatan Penguatan-LDPM berpengaruh positif terhadap efektivitas Gapoktan.
\end{abstract}




\section{PENGANTAR}

Pada tahun 2009 Badan Ketahanan Pangan Kementerian Pertanian mencanangkan kegiatan Penguatan Lembaga Distribusi Pangan Masyarakat (Penguatan-LDPM). Kegiatan ini muncul sebagai salah satu solusi dalam mengatasi berbagai masalah ketahanan pangan yang berkembang dewasa ini. Selain itu juga, sebagai respon dari adanya perubahan lingkungan strategis secara global yang ditandai oleh pergerakan harga-harga pangan strategis, kenaikan harga minyak bumi dunia, perubahan iklim dan pemanasan global, maupun sebagai dampak dari krisis finansial global yang mempengaruhi daya beli konsumen miskin, dan meningkatnya kerawanan pangan terutama di negaranegara berkembang (Satria dkk, 2008). Kegiatan Penguatan-LDPM bertujuan untuk meningkatkan dan mengembangkan: (1) kemampuan kelembagaan Gabungan Kelompoktani (Gapoktan), (2) unit usaha distribusi dan pengolahan hasil pertanian dalam rangka mendorong stabilisasi harga pangan strategis, (3) kemampuan unit usaha distribusi pemasaran Gapoktan dan memperluas jejaring pemasaran dengan mitra di luar wilayahnya, dan (4) unit cadangan pangan dengan tersedianya gudang Gapoktan untuk menyimpan gabah/beras dalam rangka memenuhi kebutuhan anggotanya (BKP, 2009). Sasaran dari pelaksanaan kegiatan PenguatanLDPM tahun 2009 adalah 546 Gapoktan di 27 provinsi sentra produksi padi dan atau jagung. Setiap Gapoktan akan memperoleh dana Bansos senilai Rp 150.000.000,00 (seratus lima puluhjutarupiah). Dana tersebut dipergunakan sebagai berikut: (1) pembangunan/rehabilitasi gudang maksimal Rp 30.000.000,00 (tiga puluh juta rupiah) sebagai sarana penyimpanan gabah/beras/jagung; (2) pembelian dan pengolahan gabah/beras/jagung dari petani; dan (3) penyediaan cadangan pangan bagi anggota yang miskin.

Berangkat dari kondisi tersebut, partisipasi elemen kelembagaan petani sasaran penerima manfaat seperti petani, kelompoktani, dan Gapoktan diperlukan dalam menentukan keberhasilan kegiatan ini. Partisipasi petani yang tergabung dalam wadah Gapoktan menjadi penting posisinya dalam kegiatan Penguatan-LDPM karena keterlibatan aktif dan kerjasama yang dilakukan baik dengan sesama anggota maupun pengurus Gapoktan akan menentukan kinerja efektivitas Gapoktan itu sendiri. Berdasarkan hasil penelitian Goldsmith dan Blustain (Ndraha, 1990) mengambil lokasi penelitian di Jamaika bahwa anggota masyarakat termasuk petani di dalamnya akan tergerak berpartisipasi jika: (1) partisipasi dilakukan melalui organisasi atau kelompok yang sudah dikenal atau yang sudah ada di tengah-tengah masyarakat; (2) partisipasi memberikan manfaat kepada masyarakat yang bersangkutan; (3) manfaat yang diperoleh melalui partisipasi tersebut dapat memenuhi kepentingan masyarakat yang bersangkutan; dan (4) dalam proses partisipasi terjamin adanya kontrol yang dilakukan oleh masyarakat.

Lebih lanjut Husodo (2006) mengemukakan bahwa partisipasi akan efektif apabila dilaksanakan secara kolektif dalam wadah kelompok. Hal demikian akan menghasilkan sinergi yang pada gilirannya akan menghasilkan manfaat ekonomi yang dapat dinikmati oleh semua pihak. Adapun wujud partisipasi yang dapat diberikan oleh anggota Gapoktan pada suatu kegiatan yaitu: ide/gagasan, keterampilan, tenaga, harta benda, dan uang (Hamidjoyo, 1991). Setiap anggota Gapoktan yang berperan serta aktif pada kegiatan di Gapoktan akan memberikan kontribusi yang berbeda sebagaimana yang diungkapkan oleh Daniel et al (2006) bahwa tingkat partisipasi petani sebagai anggota masyarakat tidak sama tergantung sejauh mana keterlibatan petani tersebut dalam memecahkan masalah yang dihadapi.

Mardikanto (2007) mengemukakan bahwa partisipasi adalah suatu bentuk keterlibatan dan keikutsertaan secara aktif dan sukarela, baik karena alasan-alasan dari dalam (intrinsik)maupundariluar(ekstrinsik) dalam keseluruhan proses kegiatan yang mencakup: pengambilan keputusan dalam perencanaan, pelaksanaan, pemantauan dan evaluasi, serta pemanfaatan hasil kegiatan 
yang dicapai. Berbagai studi penelitian terdahulu menghasilkan bahwa faktor internal yang mempengaruhi partisipasi anggota Gapoktan pada suatu kegiatan adalah usia, pendapatan, dan motivasi (Pudjianto, 2009; Husodo, 2006), sedangkan faktor eksternal atau faktor diluar diri yang mempengaruhi partisipasi anggota Gapoktan pada suatu kegiatan antara lain: peranan penyuluh, intensitas menerima sosialisasi kegiatan, kepemimpinan Gapoktan, dan kepemimpinan kelompoktani (Pudjianto, 2009; Tjokroamidjojo, 1996). Faktor-faktor tersebut juga diduga mempengaruhi partisipasi anggota Gapoktan pada kegiatan Penguatan-LDPM.

Peran serta dan keterlibatan aktif anggota Gapoktan pada kegiatan Penguatan-LDPM sendiri akan menentukan keberhasilan Gapoktan dalam mencapai tujuannya sebagaimana yang diungkapkan oleh Steers (1985). Efektivitas Gapoktan pada dasarnya ditentukan dari akumulasi efektivitas yang dilakukan oleh anggotanya. Dengan kata lain, apabila setiap anggota Gapoktan berkoordinasi melakukan tugas dan pekerjaannya masing-masing dengan baik, maka efektivitas Gapoktan secara keseluruhan akan muncul. Namun demikian prestasi seorang anggota Gapoktan tidak juga dapat dikatakan sebagai keberhasilan atau keefektifan Gapoktan secara keseluruhan. Untuk menilai apakah suatu Gapoktan dikatakan efektif atau tidak, maka secara keseluruhan ditentukan oleh tercapai tidaknya tujuan Gapoktan itu sendiri menurut kolektivitas anggotanya dan kepuasan anggotanya.

Berdasarkan kondisi di atas, menarik untuk dikaji lebih mendalam beberapa permasalahan yang juga menjadi fokus perhatian dalam penelitian tentang Kegiatan Penguatan-LDPM ini, yaitu (1) Bagaimana tingkat partisipasi anggota Gapoktan pada Kegiatan Penguatan-LDPM?; (2) Apa saja faktor-faktor yang mempengaruhi partisipasi anggota Gapoktan?; Bagaimana hubungan antar berbagai faktor yang mempengaruhi partisipasi anggota
Gapoktan?; (4) Bagaimana pengaruh partisipasi anggota Gapoktan terhadap efektivitas Gapoktan yang dilihat dari sisi kepuasan anggota Gapoktan dan proses mencapai tujuan Gapoktan yang meliputi: (1) proses tersalurkannya dana bansos untuk pembangunan gudang Gapoktan, (2) proses meningkatnya perputaran aktivitas pembelian gabah/beras Gapoktan dari petani, dan (3) proses tersedianya cadangan pangan untuk memenuhi kebutuhan anggotanya?; dan (5) Bagaimana efektivitas Gapoktan dilihat dari aspek pengembangan lembaga Gapoktan?.

Tulisan ini menggunakan mixed methods sebagai metode dasar, di mana metode kuantitatif didukung oleh metode kualitatif yang digunakan keduanya secara simultan atau bersamaan. Metode kualitatif dalam penelitian ini berfungsi untuk menjelaskan temuan-temuan kuantitatif (Tashakkori dan Teddlie, 2010). Penelitian ini mengambil sampel 91 responden dan 15 informan di Gapoktan Mitra Sari, Kecamatan Pamijahan dan Gapoktan Subur Tani, Kecamatan Tanjung Sari, Kabupaten Bogor. Penentuan sampel responden menggunakan teknik proportionate stratified random sampling, sedangkan penentuan informan ditentukan secara purposive sesuai dengan kriteria informan yang mengetahui dan paham tentang kegiatan Penguatan-LDPM.

Teknik pengumpulan data yang dilakukan dalam penelitian ini adalah: menggunakan kuesioner, pengamatan langsung, wawancara mendalam, dokumentasi, dan studi pustaka. Adapun untuk menganalisis data terdapat 5 (lima) cara yang digunakan. Pertama, analisis interval kelas untuk menguji hipotesis tentang tingkat partisipasi anggota Gapoktan. Penentuan interval kelas menggunakan rumus sebagaimana digunakan oleh Nazir bahwa interval kelas merupakan hasil bagi antara range (nilai maksimal - nilai minimal) dengan jumlah interval kelas yang diinginkan dalam hal ini rendah, sedang, dan tinggi (Nazir, 2003). Kedua, analisis regresi linear berganda untuk menguji hipotesis 
tentang faktor-faktor yang mempengaruhi partisipasi anggota Gapoktan pada Kegiatan Penguatan-LDPM. Hipotesis model yang dikembangkan adalah sebagai berikut:

$$
\begin{aligned}
Y= & b_{0}+b_{1} X_{1}+b_{2} X_{2}+b_{3} X_{3}+b_{4} X_{4}+b_{5} X_{5} \\
& +b_{6} X_{6}+b_{7} X_{7}+e
\end{aligned}
$$

Di mana:

Y : Partisipasi anggota Gapoktan pada Kegiatan PenguatanLDPM

bo : Intersep

b1 - b7 : Koefisien regresi variabel X1-X7

X1 : Usia

X2 : Motivasi

X3 : Pendapatan

X4 : Peranan penyuluh

X5 : Intensitas menerima sosialisasi kegiatan

X6 : Kepemimpinan Gapoktan

X7 : Kepemimpinan kelompoktani

e : galat

Ketiga, Sebagai pengembangan dari hasil model regresi linear berganda dan untuk mengetahui besarnya hubungan pengaruh baik langsung maupun tidak langsung diantara variabel-variabel, maka digunakan analisis jalur (path analiysis). Keempat, analisis regresi linear sederhana digunakan untuk menguji hipotesis tentang pengaruh partisipasi anggota Gapoktan terhadap efektivitas Gapoktan pada Kegiatan Penguatan-LDPM. Kelima, model interaktif yang digunakan untuk menganalisis efektivitas Gapoktan dari segi pengembangan lembaga Gapoktan secara kualitatif. Menurut Miles dan Huberman (Salim, 2006) komponen-komponen analisis data yang dilakukan mencakup pengumpulan data, reduksi data, penyajian data, dan penarikan kesimpulan secara interaktif saling berhubungan selama dan sesudah pengumpulan data.

\section{PEMBAHASAN}

Tingkat Partisipasi Anggota Gapoktan Pada Kegiatan Penguatan-LDPM

Partisipasi anggota Gapoktan adalah peran serta atau keterlibatan anggota Gapoktan penerima Program Dana Bansos Kegiatan Penguatan-LDPM pada tahap perencanaan, pelaksananaan, pemantauan dan evaluasi, serta pemanfaatan hasil baik dalam wujud ide, tenaga, dan materi. Pengertian ini mengadopsi dari konsep yang diungkapkan oleh Yadav (Mardikanto, 1987) yang membagi partisipasi dalam empat tingkatan kegiatan pembangunan yang meliputi: tahap perencanaan, pelaksananaan, pemantauan serta evaluasi, dan pemanfaatan hasil.

Tabel 1.

Tingkat Partisipasi Anggota Gapoktan pada Kegiatan Penguatan Lembaga Distribusi Pangan Masyarakat Pertahap Kegiatan di Kabupaten Bogor

\begin{tabular}{lllll}
\hline \multirow{2}{*}{ No } & \multirow{2}{*}{ Tahap } & \multicolumn{2}{c}{ Skor } & \multirow{2}{*}{ Tingkat Partisipasi Anggota Gapoktan } \\
\cline { 3 - 4 } & & Rata-Rata & Maksimal & ( c) $\mathbf{~ = ~ a / b ~ x ~ 1 0 0 \% ~}$ \\
\hline 1 & Perencanaan & 12,85 & $\mathbf{( b )}$ & 27,33 \\
2 & Pelaksanaan & 8,22 & 34 & 24,18 \\
3 & Pemantauan dan Evaluasi & 13,59 & 54 & 25,17 \\
4 & Pemanfaatan Hasil & 3,03 & 18 & 16,85 \\
\hline $\mathbf{5}$ & Partisipasi Keseluruhan & 37,69 & 153 & 24,63 \\
\hline
\end{tabular}

Sumber: Data Primer, 2012 
Berdasarkan hasil penelitian sebagaimana terangkum dalam Tabel 1 menunjukkan bahwa tingkat partisipasi anggota Gapoktan secara menyeluruh mulai dari tahap perencanaan hingga pemanfaatan hasil masih tergolong rendah yaitu sebesar 24,63 persen. Kondisi tersebut disebabkan sebagai berikut: (1) minimnya sosialisasi kegiatan yang diberikan ketua beserta pengurus Gapoktan dan penyuluh selaku pendamping kepada anggota Gapoktan, (2) banyaknya anggota Gapoktan yang jarang bahkan tidak hadir pada rapat-rapat yang diselenggarakan pada masing-masing kegiatan di setiap tahap, dan (3) kontribusi yang diberikan oleh anggota Gapoktan baik dalam bentuk ide, tenaga, maupun materi secara keseluruhan juga rendah.

Tahap pemanfaatan hasil dan tahap pelaksanaan perlu mendapat perhatian khusus mengingat tahap tersebut berada di bawah rata-rata secara keseluruhan terutama partisipasi anggota Gapoktan pada tahap pemanfaatan hasil yang hanya mencapai 16,85 persen. Penyebabnya adalah rendahnya anggota Gapoktan memberikan sumbangan ide, tenaga, dan materi terutama dari sisi kontribusi ide atau gagasan. Anggota Gapoktan mayoritas enggan untuk menyebarluaskan informasi manfaat dari kegiatan Penguatan-LDPM kepada sesama anggota yang pasif atau petani yang belum bergabungdalam Gapoktankarenaminimnya sosialisasi pada tahap ini yang diberikan oleh ketua Gapoktan atau penyuluh baik secara formal maupun informal. Minimnya sosialisasi tersebut diiringi juga rendahnya partisipasi secara materi. Anggota Gapoktan meskipun sudah memperoleh keuntungan dari aktivitas penjualan gabah/beras ke Gapoktan, tetapi tidak mau mengisi uang kas ke Gapoktan. Keengganan tersebut dikarenakan mengetahui sesama anggota lainnya tidak mengisi uang kas Gapoktan ditambah lagi tidak adanya sanksi dari Gapoktan itu sendiri. Di sisi lain, keuntungan yang diperoleh Gapoktan dari usaha jual/beli gabah beras anggotanya tidak diinformasikan kepada anggotanya. Kurangnya keterbukaan
Ketua dan Pengurus Gapoktan dalam menginformasikan keuntungan dari usaha Gapoktan sebagai bagian dari manfaat yang dapat diperoleh anggota menambah argumen partisipasi anggota Gapoktan pada tahap ini menjadi rendah.

Pada tahap pelaksanaan, partisipasi anggota Gapoktan pada kegiatan PenguatanLDPM rendah karena sosialisasi kegiatan yang diberikan hanya sebatas kepada orangorang yang dekat baik dari segi kedekatan hubungan maupun tempat tinggal yang berdekatan dengan pengurus. Rendahnya sosialisasi terhadap pelaksanaan kegiatan kemudian berdampak pada rendahnya kontribusi secara materi yang diberikan oleh anggota Gapoktan seperti dalam hal; (1) memberikan bantuan semen, batu bata/batako, kayu, asbes/genteng, paku, kawat, besi untuk pembangunan gudang Gapoktan, (2) mengeluarkan uang untuk membeli makanan dan minuman pada saat pembangunan gudang Gapoktan, dan (3) menjual gabah/beras ke Gapoktan. Kondisi tersebut dikarenakan pendapatan perbulan mayoritas anggota Gapoktan (62,64 persen) yang hanya berkisar antara Rp400.000,00 sampai dengan Rp1.299.999,00. Anggota Gapoktan enggan untuk berkontribusi karena lebih memfokuskan pada pemenuhan kebutuhan sehari-hari keluarganya.

Bentuk partisipasi yang kebanyakan diberikan oleh anggota Gapoktan pada tahap pelaksanaan dalam bentuk tenaga meliputi: (1) mengajak sesama anggota Gapoktan untuk bergotong-royong dalam pembangunan gudang Gapoktan, (2) ikut serta membangun gudang Gapoktan, dan (3) membantu Gapoktan mengumpulkan gabah/beras yang dibeli dari anggota. Anggota Gapoktan akan sukarela dan lebih banyak mengerahkan tenaganya yang mengandalkan kekuatan fisik dibandingkan memberikan sumbangsih pemikiran terlebih materi seiring dengan hasil studi yang dilakukan oleh (Tanjungsari, 2010).

Pada tahap perencanaan, meskipun secara persentase tertinggi di atas semua tahap yaitu sebesar 27,33 persen, tetapi 
partisipasi anggota Gapoktan pada tahap ini masih tergolong rendah. Beberapa peran serta dilakukan anggota Gapoktan pada tahap ini antara lain: (1) menghadiri rapat perencanaan kegiatan, (2) menginformasikan jumlah anggota yang miskin, (3) menginformasikan perkiraan biaya pembangunan gudang, (4) memberikan ide dalam merancang bentuk bangunan gudang Gapoktan, dan (5) memberikan informasi rata-rata hasil panen. Adapun penyebab rendahnya tingkat partisipasi pada tahap ini adalah sikap pengambil keputusan yaitu ketua Gapoktan dan pengurus tentang rencana kegiatan yang seringkali tidak menampung aspirasi anggotanya. Kondisi tersebut kemudian membuat anggota Gapoktan jarang memberikan informasi tentang perencanaan kegiatan Penguatan-LDPM karena hal tersebut selain tidak akan diperhatikan oleh ketua beserta pengurus Gapoktan juga anggota Gapoktan beranggapan bahwa hal tersebut dapat dilakukan oleh ketua maupun pengurus Gapoktan. Hasil penelitian ini seiring dengan studi yang dilakukan oleh Arifah (2002) bahwa meskipun petani mempunyai kesempatan yang sama dalam mengeluarkan pendapat ketika menyusun rencana, tetapi tidak semua terdorong untuk memberikan kontribusi.

Tingkat keterlibatan anggota Gapoktan pada tahap pemantauan dan evaluasi hanya mencapai 25,17 persen. Rendahnya tingkat partisipasi tersebut dikarenakan anggota Gapoktan minim memberikan kontribusi dalam hal, yaitu (1) menilai atau memberi masukan terhadap kinerja ketua dan pengurus Gapoktan serta penyuluh sebagai pendamping kegiatan Penguatan-LDPM agar usaha Gapoktan dapat berkembang, (2) membantu Gapoktan untuk mengingatkan kepada sesama anggota untuk tidak menjual gabah/beras ke tengkulak, dan (3) hadir dalam rapat anggota tahunan Gapoktan. Hal lain yang menyebabkan rendahnya partisipasi anggota Gapoktan pada tahap ini adalah mereka enggan dalam membantu ketua Gapoktan dalam pembuatan laporan bulanan hasil kegiatan Penguatan-LDPM. Anggota Gapoktan beranggapan bahwa pihak yang lebih banyak berkepentingan dalam tahap ini adalah ketua dan pengurus Gapoktan, serta penyuluh pertanian yang berfungsi sebagai pendamping kegiatan, dan Tim Teknis Kabupaten. Hasil studi pada tahap pemantauan dan evaluasi ini sama halnya dengan yang dilakukan oleh Swedianti (2011); Pudjianto (2009); dan Arifah (2002).

\section{Faktor-Faktor yang Mempengaruhi Partisipasi Anggota Gapoktan pada Kegiatan Penguatan-LDPM}

Faktor-faktor yang diduga mempengaruhi partisipasi anggota Gapoktan pada Kegiatan Penguatan-LDPM adalah usia, motivasi, pendapatan, peranan penyuluh, intensitas menerima sosialisasi kegiatan, kepemimpinan Gapoktan, dan kepemimpinan Kelompoktani. Untuk menganalisis faktor-faktor tersebut, maka digunakan program Statistical Package for the Social Sciences (SPSS) 16 dengan metode backward. Metode pengolahan data dengan cara ini adalah memasukan semua variabel bebas yang diduga berpengaruh secara keseluruhan, kemudian secara otomatis program SPSS 16 akan menghilangkan satu persatu variabel bebas yang tidak signifikan berpengaruh. Dari 7 (tujuh) variabel yang diduga mempengaruhi partisipasi anggota Gapoktan pada kegiatan Penguatan-LDPM, variabel peranan penyuluh, kepemimpinan Gapoktan, dan kepemimpinan Kelompoktani tidak berpengaruh, sehingga keluar dari model. Adapun hasil analisis yang mempengaruhi partisipasi anggota Gapoktan pada kegiatan Penguatan-LDPM sebagaimana terlihat pada Tabel 2 . 
Tabel 2.

Hasil Analisis Regresi Linear Berganda

Mengenai Faktor-Faktor Berpengaruh Signifikan terhadap

Partisipasi Anggota Gapoktan pada Kegiatan Penguatan-LDPM (Model 4)

\begin{tabular}{|c|c|c|c|c|}
\hline No & Variabel & Koefisien Regresi & t-hitung & Sig \\
\hline & konstanta & 1,937 & 0,229 & 0,819 \\
\hline 1 & Usia $(X 1)$ & $-0,426$ & 3,480 & 0,001 \\
\hline 2 & Motivasi (X2) & 0,123 & 2,064 & 0,042 \\
\hline 3 & Pendapatan (X3) & 0,00004506 & 17,137 & 0,000 \\
\hline 4 & Intensitas menerima sosialisasi kegiatan (X5) & 0,313 & 3,027 & 0,003 \\
\hline
\end{tabular}

\section{Keterangan:}

N $: 91$

R $: 0,990$

R Square $\quad: 0,979$

Adjusted R Square $\quad: 0,979$

F-hitung :1.027,201

F-tabel $\alpha=0,05 \quad: 2,4953$

t-tabel $\alpha=0,05 \quad: 1,99133$

sig $\quad: 0,000$

Persamaan Model: $Y=-0,426 X_{1}+0,123 X_{2}+$ $0,00004506 X_{3}+0,313 X_{5}$

Sumber: Data Primer, 2012 diolah dengan SPSS 16 (Model Backward)

Berdasarkan hasil analisis sebagaimana tercantum pada Tabel 2, nilai $\mathrm{R}$ Square sebesar 0,979 menunjukkan bahwa variabel bebas yaitu usia, pendapatan, motivasi, dan intensitas menerima sosialisasi kegiatan dapat menjelaskan variabel terikat yaitu partisipasi anggota Gapoktan pada Kegiatan PenguatanLDPM sebesar 97,9 persen, sedangkan sisanya 2,1 persen dijelaskan faktor-faktor lainnya di luar model.Hasilanalisisjuga memperlihatkan faktor usia berpengaruh negatif sedangkan faktor motivasi, pendapatan, dan intensitas menerima sosialisasi kegiatan berpengaruh positif terhadap terhadap partisipasi anggota Gapoktan pada kegiatan Penguatan-LDPM. Nilai koefisien regresi usia sebesar $-0,426$ menunjukkan bahwa semakin muda usia anggota Gapoktan, maka terjadi peningkatan partisipasi sebesar 0,426 satuan.

Anggota Gapoktan yang memiliki motivasi kuat akan meningkatkan partisipasinya pada kegiatan penguatanLDPM guna memenuhi kebutuhan seperti sandang, pangan, papan (existence), berhubungan sosial (relatedness), dan mengembangkan kemampuan diri (growth) sebagaimana yang dikonsepsikan oleh Alderfer (Umstot, 1988). Keinginan dan dorongan yang kuat dari anggota Gapoktan untuk berpartisipasi pada kegiatan Penguatan-LDPM dalam memenuhi kebutuhan akan existence antara lain: keinginan untuk memenuhi kebutuhan sandang, pangan, papan, hasil panen, memperoleh kepastian harga jual gabah/ beras, dan bebas dari rasa kuatir gagal panen.

Adapun motivasi anggota Gapoktan yang kuat untuk berpartisipasi pada kegiatan penguatan-LDPM dalam rangka memenuhi kebutuhan berhubungan sosial (relatedness) di antaranya keinginan untuk sebagai berikut: (1) meningkatkan kerjasama dengan petani, maupun pengurus Gapoktan/ Kelompoktani; (2) diperhatikan pada saat berhubungan dengan petani maupun pengurus Gapoktan/ Kelompoktani; (3) selalu berhubungan dengan ketua Gapoktan untuk memperoleh informasi terbaru tentang kegiatan Penguatan-LDPM; dan (4) bekerjasama dengan penyuluh sebagai pendamping untuk mengembangkan usaha dalam kegiatan Penguatan-LDPM. Di sisi lain, keinginan dan dorongan yang kuat dalam hal: keinginan untuk menjadi orang yang berguna bagi masyarakat terutama petani di desanya; menerapkan pengetahuan yang diberikan oleh penyuluh; menambah wawasan dan pengetahuan dari penyuluh; dan mengikuti pelatihan untuk meningkatkan keterampilan dan kemampuan merupakan beberapa motivasi anggota Gapoktan untuk berpartisipasi pada kegiatan PenguatanLDPM yang disebabkan pemenuhan kebutuhan akan pengembangan diri (growth).

Pendapatan anggota Gapoktan yang berkisar antara $R p$ 400.000,00 sampai dengan Rp 3.000.000,00 perbulan memberikan dampak 
terhadap keterlibatan dan peran aktif anggota Gapoktan pada kegiatan Penguatan-LDPM. Semakin meningkat pendapatan anggota Gapoktan akan berpengaruh pada partisipasi anggota Gapoktan itu sendiri pada kegiatan Penguatan-LDPM. Begitu pula dengan peningkatan intensitas menerima sosialisasi kegiatan, semakin sering anggota Gapoktan menerima sosialisasi kegiatan PenguatanLDPM dari ketua maupun pengurus Gapoktan serta penyuluh baik pada setiap tahap, maka akan diikuti peningkatan partisipasi anggota Gapoktan pada kegiatan Penguatan-LDPM.

Perananpenyuluhyangtidak berpengaruh secara signifikan terhadap partisipasi anggota Gapoktan lebih banyak dikarenakan minimnya frekuensi pendampingan kepada seluruh anggota Gapoktan pada kegiatan PenguatanLDPM yang rata-rata hanya 3-4 kali dalam setahun terakhir. Kondisi tersebut terjadi karena penyuluh harus membina wilayah kerja hingga 3-4 desa, padahal menurut ketentuan Peraturan Menteri Pertanian nomor 273/Kpts/OT.160/4/2007 tentang pedoman pembinaan kelembagaan petani, seharusnya penyuluh hanya membina satu desa sebagai wilayah kerjanya.

Baiknya kepemimpinanan Gapoktan yang dicirikan dengan hal-hal yang berkaitan dengan gaya ketua Gapoktan dalam mengelola Gapoktan sesuai dengan situasi dan tingkat kematangan anggota Gapoktan tidak berpengaruh terhadap peran serta dan keterlibatan aktif anggota Gapoktan pada kegiatan Penguatan-LDPM. Anggota Gapoktan tidak tergerak berkontribusi pada kegiatan Penguatan-LDPM meskipun ketua Gapoktan sudah menggunakan gaya telling (memberikan supervisi dan instruksi) ketika terdapat anggota Gapoktan yang tidak mengetahui dan tidak mau mengikuti kegiatan Penguatan-LDPM; gaya selling (memberikan dorongan dan motivasi) ketika terdapat anggota Gapoktan yang mengetahui, tetapi tidak mau mengikuti kegiatan PenguatanLDPM; gaya participating (memberikan fasilitasi) ketika terdapat anggota Gapoktan yang mengetahui, tetapi berkeinginan kuat mengikuti kegiatan Penguatan-LDPM; dan gaya delegating (memberikan asistensi dan pengarahan) ketika terdapat anggota yang mengetahui dan mau mengikuti kegiatan Penguatan-LDPM. Hal tersebut terjadi karena norma seperti pemberian apresiasi dan sanksi yang berlaku pada Gapoktan tidak berjalan secara optimal. Sama halnya dengan kepemimpinan ketua kelompoktani yang juga tidak memberikan pengaruh terhadap partisipasi anggota Gapoktan pada Kegiatan Penguatan-LDPM, selain karena tingginya permisivitas norma yang berlaku di kelompoktani juga dikarenakan minimnya kegiatan penunjang pada kegiatan PenguatanLDPM yang melibatkan seluruh anggota.

\section{Hubungan Berbagai Faktor yang Saling Mempengaruh Partisipasi Anggota Gapoktan pada Kegiatan Penguatan-LDPM}

Sebagai pengembangan dari analisis regresi linear berganda, maka dapat digunakan analisis jalur (path analysis) sebagaimana dikemukakan Muller (Hariadi, 2011) untuk mengetahui hubungan antarberbagai faktor (usia, pendapatan, motivasi, dan intensitas menerima sosialisasi kegiatan) yang saling mempengaruhi partisipasi anggota Gapoktan pada Kegiatan Penguatan-LDPM.
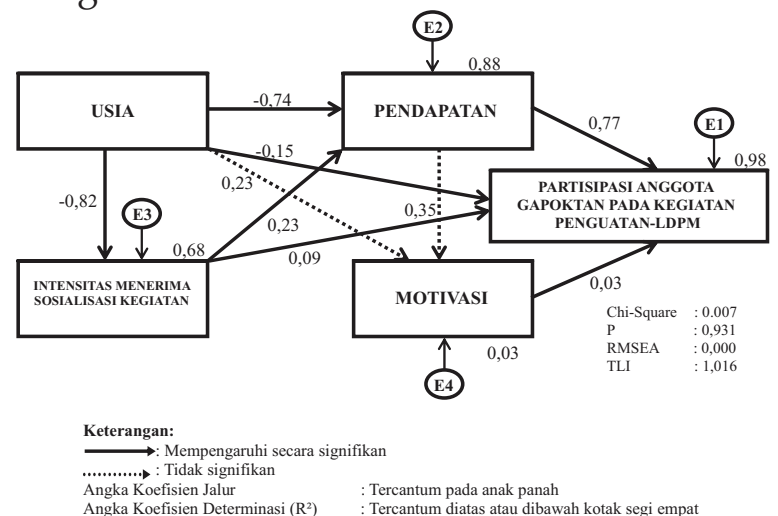

Gambar 1.

Struktur Model Analisis Jalur Variabel-Variabel yang Berpengaruh terhadap Partisipasi Anggota Gapoktan pada Kegiatan Penguatan-LDPM

Sumber: Data Primer, 2012, diolah dengan Amos 5 
Berdasarkan hasil analisis jalur sebagaimana terangkum pada Gambar 1, faktor usia tampak mempengaruhi pendapatan $(-0,739)$, intensitas menerima sosialisasi kegiatan $(-0,822)$, dan partisipasi anggota Gapoktan pada Kegiatan PenguatanLDPM (-0,150). Tim teknis kabupaten, penyuluh, ketua Gapoktan/Kelompoktani beserta pengurus harus memperhatikan faktor-faktor yang mempengaruhi partisipasi anggota Gapoktan pada Kegiatan PenguatanLDPM, terutama faktor intensitas menerima sosialisasi kegiatan $(0,09)$ selain faktor usia yang memiliki pengaruh paling besar terhadap intensitas menerima sosialisasi kegiatan secara berbanding terbalik. Artinya supaya sosialisasi kegiatan dapat berjalan dengan efektif selain intensitas pertemuan diperbanyak, akan lebih efektif jika lebih banyak memperhatikan usia anggota Gapoktan yang berusia lebih muda dibandingkan anggota Gapoktan yang sudah berusia tua. Hasil penelitian tersebut sejalan dengan yang dikemukakan oleh Soedijanto (1996) bahwa kemampuan belajar seseorang dalam mengikuti suatu kegiatan akan berkurang secara bertahap dan terasa sangat nyata setelah berusia 55 atau 60 tahun. Lionberger (Mardikanto, 1993) sendiri mengatakan bahwa semakin tua seseorang yaitu di atas 50 tahun, biasanya semakin lamban mengadopsi inovasi dan cenderung hanya menerapkan kegiatan yang biasa dilaksanakan oleh masyarakat setempat.

Pendapatan anggota Gapoktan berpengaruh langsung paling besar terhadap partisipasi anggota Gapoktan pada Kegiatan Penguatan-LDPM. Meskipun mayoritas pendapatan anggota berkisar antara Rp 400.000,00 sampai dengan $\mathrm{Rp} 1.299 .999,00$ (63 persen) harus terus ditingkatkan sehingga memberikan pengaruh terhadap meningkatnya partisipasi anggota Gapoktan pada Kegiatan Penguatan-LDPM secara menyeluruh. Ketua Gapoktan/ Kelompoktani beserta pengurus dan penyuluh harus membuat inovasi dan meningkatkan pendapatan anggota dengan cara mempercepat perputaran penjualan gabah/beras anggota ke mitra pemasaran dan mengembangkan usaha Gapoktan dengan memaksimalkan keuntungan yang diperoleh dengan melibatkan seluruh anggotanya melalui pembagian kerja atau tugas yang jelas.

Pendapatan anggota Gapoktan tidak berpengaruh terhadap motivasi untuk berpartisipasi pada kegiatan PenguatanLDPM yang disebabkan oleh kebutuhan akan eksistensi diri, berhubungan sosial, dan pengembangan diri. Hal tersebut terjadi karena sosialisasi kegiatan sangat minim dan tidak seluruh anggota mengetahui tentang kegiatan tersebut membuat pendapatan tidak berpengaruh terhadap motivasi. Begitupula dengan usia yang tidak berpengaruh terhadap motivasi, dengan minimnya sosialisasi kegiatan baik anggota Gapoktan yang berusia muda atau tua tidak akan termotivasi untuk berpartisipasi pada kegiatan Penguatan-LDPM untuk memenuhi kebutuhan eksistensi diri, berhubungan sosial, dan pengembangan diri.

Motivasi anggota kelompoktani yang masihmemilikipengaruhrelatifrendah $(0,032)$ terhadap partisipasi anggota Gapoktan pada Kegiatan Penguatan-LDPM, tidak boleh luput dari perhatian ketua Gapoktan/Kelompok tani beserta pengurus dan penyuluh yang bersinggungan langsung setiap hari dengan anggota kelompoktani. Motivasi anggota Gapoktan untuk berpartisipasi pada kegiatan Penguatan-LDPM dalam rangka memenuhi kebutuhan existence, relatedness, dan growth harus difasilitasi oleh ketua Gapoktan/Kelompoktani beserta pengurus dan penyuluh. Bentuk fasilitasi tersebut dapat berupa: mencari jaringan pemasaran bersama-sama antara petani, pengurus Gapoktan/Kelompoktani, dan pendamping; mengembangkan dan menerapkan pengetahuan atau inovasi baru yang diperoleh dari pelatihan untuk meningkatkan produktivitas padi seperti sekolah lapang yang diselenggarakan oleh Penyuluh. 


\section{Pengaruh Partisipasi Anggota Gapoktan terhadap Efektivitas Gapoktan pada Kegiatan Penguatan- LDPM}

Salah satu faktor yang mempengaruhi efektivitas suatu organisasi adalah adanya dukungan atau partisipasi anggota dalam organisasi tersebut. Sills mengemukakan bahwa efektivitas kelompok adalah keberhasilan kelompok untuk mencapai tujuannya yang dapat dilihat pada tercapainya keadaan atau perubahanperubahan (fisik maupun non-fisik) yang memuaskan anggotanya (Steers, 1985; Sills dalam Mardikanto, 1993).

Tabel 3.

Hasil Analisis Regresi Linear Sederhana Mengenai Partisipasi Anggota Gapoktan pada Kegiatan Penguatan-LDPM

Berpengaruh terhadap Efektivitas Gapoktan

\begin{tabular}{lllll}
\hline No & Variabel & $\begin{array}{l}\text { Koefisien } \\
\text { Regresi }\end{array}$ & t-hitung & Sig \\
\hline 1 & konstanta & 25,229 & 15,718 & 0,000 \\
2 & Partisipasi & 0,282 & 8,742 & 0,000 \\
\hline
\end{tabular}

Keterangan:

$\begin{array}{ll}\mathrm{N} & : 91 \\ \mathrm{R} & : 0,680 \\ \text { R Square } & : 0,462 \\ \text { Adjusted R Square } & : 0,456 \\ \text { F-hitung } & : 76,423 \\ \text { F-tabel } \alpha=0,05 & : 3,961333 \\ \text { t-tabel } \alpha=0,01 & : 2,640667 \\ \text { t-tabel } \alpha=0,05 & : 1,9903\end{array}$

Persamaan Model: $Y=25,229+0,282 X$

Sumber: Data Primer, 2012 diolah menggunakan SPSS 16

Tabel 3 memperlihatkan bahwa nilai sig variabel partisipasi anggota Gapoktan pada Kegiatan Penguatan-LDPM lebih kecil dari taraf signifikansi $=0,05$ atau nilai t-hitung variabel partisipasi anggota Gapoktan pada Kegiatan Penguatan-LDPM sebesar 8,742 lebih besar dari nilai t-tabel dengan nilai 1,9903. Jika nilai uji sig lebih kecil dari taraf signifikansi yang telah ditetapkan atau nilai t-hitung lebih besar dari nilai t-tabel, maka hipotesis diterima. Peningkatan partisipasi anggota Gapoktan pada kegiatan Penguatan-LDPM akan diikuti pula dengan peningkatan efektivitas Gapoktan dalam proses mencapai tujuannya serta kepuasan anggota Gapoktan. Adapun proses dalam mencapai tujuan Gapoktan meliputi proses: (1) tersalurkannya dana bansos untuk pembangunan gudang Gapoktan, (2) meningkatnya perputaran aktivitas pembelian gabah/beras Gapoktan kepada anggotanya, dan (3) tersedianya cadangan pangan untuk memenuhi kebutuhan anggotanya.

\section{Efektivitas Gapoktan dalam Pengembangan Lembaga Gapoktan}

Pengembangan lembaga Gapoktan pada kegiatan Penguatan-LDPM di Kabupaten Bogor dari aspek perluasan jaringan pemasaran belum sepenuhnya optimal dilakukan oleh Gapoktan penerima, hal ini terlihat nyata dengan yang dihadapi Gapoktan Mitra Sari. Gabah/beras yang dibeli dari anggotanya selama ini dalam sebulannya hanya dijual kepada masyarakat sekitar (2-4 ton), Pasar Leuwiliang (3-5 ton), dan kios Gapoktan di Pasar Laladon, Bogor (6-8 ton). Sulitnya memasarkan beras lebih banyak dikarenakan belum terlibatnya secara penuh anggota dalam Kegiatan PenguatanLDPM dan aktivitas anggota lebih banyak terfokus pada kegiatan produksi (on-farm). Ditambah lagi dengan Ketua Gapoktan yang sudah berusia lanjut dan belum ada sumber daya manusia Gapoktan yang mau untuk menjadi pengganti Ketua Gapoktan saat ini membuat pengembangan usaha yang dilakukan dalam rangka meningkatkan skala usaha menjadi sulit untuk diwujudkan.

Kondisi berbeda dialami pada Gapoktan Subur Tani, meskipun keterlibatan anggotanya juga relatif minim, tetapi aktivitas jual-beli gabah/beras dan jaringan pemasaran cukup luas, begitupula dengan pengembangan usaha yang dilakukan cukup berkembang. Pemasaran beras yang dilakukan oleh Gapoktan Subur Tani selama ini antara lain: masyarakat sekitar; pedagang grosir dan eceran di Cikalong, Depok, Bekasi, Cibubur, Jonggol, Pasar Induk Beras Cipinang, dan Pasar Ciawi; dan Gapoktan 
sesama penerima Kegiatan PenguatanLDPM di Kabupaten: Bandung Barat, Purwakarta, Karawang, dan Indramayu. Dalam sebulannya rata-rata kurang lebih 20 ton beras yang dapat dijual oleh Gapoktan Subur Tani kepada mitra Gapoktan. Harga yang ditawarkan oleh Gapoktan bervariasi tergantung pada kualitas beras itu sendiri dan juga kondisi harga pasar yang berkembang. Adapun harga pembelian beras yang dilakukan oleh Gapoktan kepada anggotanya memiliki selisih antara Rp200,00/kg sampai dengan Rp300,00/kg dengan sistem pembayaran secara tunai langsung. Harga pembelian Gapoktan tersebut masih di atas HPP yaitu Rp6.000,00/kg sesuai dengan tujuan dari kegiatan Penguatan-LDPM itu sendiri. Cara pembayaran yang dilakukan antara Gapoktan Subur Tani dengan mitra adalah membayar uang muka sebesar 1015 persen dari total nilai transaksi yang disepakati. Kepercayaan yang dibangun
Gapoktan Subur Tani dengan mitra lebih banyak dikarenakan jaringan yang dimiliki oleh Ketua Gapoktan, bukan disebabkan oleh kolektivitas seluruh anggotanya. Ketua Gapoktan yang merupakan mantan kepala desa dan telah menangani berbagai macam proyek kegiatan, sehingga cukup berpengalaman dalam mencari mitra pemasaran.

Dari segi kerjasama/kemitraan dengan Gapoktan lain, Gapoktan Mitra Sari belum pernah melakukan kerjasama dengan Gapoktan sekitarnya baik dari sisi penjajagan pemasaran beras maupun pengembangan usaha. Tercatat hanya pada tahun 2010 Gapoktan Mitra Sari bekerjasama membeli gabah Gapoktan Subur Tani sebanyak 5 ton. Di lain pihak, kerjasama yang dilakukan oleh Gapoktan Subur Tani relatif lebih baik dibandingkan dengan Gapoktan Mitra Sari sebagaimana terangkum pada Tabel 4.

Tabel 4

Kemitraan/Kerjasama Gapoktan Subur Tani

dengan Sesama Gapoktan Penerima Kegiatan Penguatan-LDPM

\begin{tabular}{|c|c|c|c|c|c|c|}
\hline \multirow[b]{2}{*}{ No } & \multirow[b]{2}{*}{ Keterangan } & \multicolumn{5}{|c|}{ Mitra Gapoktan } \\
\hline & & $\begin{array}{c}\text { Mitra Usaha } \\
\text { Mandiri (Bandung } \\
\text { Barat) }\end{array}$ & $\begin{array}{c}\text { Kiara Makmur } \\
\text { (Kab.Purwakarta) }\end{array}$ & $\begin{array}{l}\text { Sinar Langgeng } \\
\text { (Kab.Karawang) }\end{array}$ & $\begin{array}{c}\text { Jaya Tani (Kab. } \\
\text { Indramayu) }\end{array}$ & $\begin{array}{l}\text { Harapan Murni } \\
\text { (Kab.Bekasi) }\end{array}$ \\
\hline I. & Penjualan & & & & & \\
\hline 1 & $\begin{array}{l}\text { Jenis Gabah/ } \\
\text { Beras }\end{array}$ & GKG & GKG & GKP & GKP & - \\
\hline 2 & $\begin{array}{l}\text { Harga (Rp/ } \\
\left.(\mathrm{Kg})^{*}\right)\end{array}$ & $3.800,-$ & $3.800,-$ & $3.400,-$ & $3.400,-$ & - \\
\hline 3 & Kuantitas ${ }^{* *}$ ) & 4 ton & 7,5 kuintal & 20 ton & 9 ton & - \\
\hline 4 & Bulan $^{* * *}$ ) & Oktober & Oktober & Februari & Februari & - \\
\hline II. & Pembelian & & & & & \\
\hline 1 & $\begin{array}{l}\text { Jenis Gabah/ } \\
\text { Beras }\end{array}$ & GKG & - & $\begin{array}{l}\text { GKG dan Beras } \\
\text { (kepala) }\end{array}$ & $\begin{array}{l}\text { GKG dan Beras } \\
\text { (medium) }\end{array}$ & GKG \\
\hline 2 & Harga $(\mathrm{Rp} / \mathrm{Kg})$ & $4.100,-$ & - & $\begin{array}{l}4.200,-(G K G) \\
\text { dan } 8.100 \text { (Beras) }\end{array}$ & $\begin{array}{l}\text { 3.700,-(GKG) } \\
\text { dan 6.800 (Beras) }\end{array}$ & 3.900,- \\
\hline 3 & Kuantitas & 8 ton & - & 8 dan 9 ton & 8 dan 5 ton & 9 ton \\
\hline 4 & Bulan & Desember & - & Maret & April & April \\
\hline
\end{tabular}

Sumber: Data Primer, 2012

Keterangan:

*) Harga transaksi terakhir yang dilakukan

**) Kuantitas transaksi rata-rata yang sering dilakukan

***) kecenderungan bulan yang sering dilakukan transaksi

GKP : Gabah Kering Panen

GKG : Gabah Kering Gabah
Berdasarkan tabel 4 terlihat bahwa kerjasama jual-beli gabah/beras Gapoktan Subur Tani hingga lintas kabupaten yang melibatkan Gapoktan sesama penerima Kegiatan Penguatan-LDPM dengan kuantitas yang bervariasi. Bentuk kerjasama lain dalam rangka pengembangan usaha Gapoktan Subur Tani kepada Gapoktan sekitar penangkaran benih padi, pembelian beras 
organik, dan penjualan pupuk. Penangkaran benih dilakukan dengan beberapa anggota dekat sedangkan pengadaan pupuk bekerjasama dengan distributor setempat.

Dalam setiap musim tanam tiba, Gapoktan Subur Tani dapat memasok sekitar 3-4 ton benih kepada Gapoktan mitra dengan harga berkisar antara Rp33.000,00 sampai dengan Rp35.000,00. Adapun jumlah pupuk yang dijual ke Gapoktan Berkah Mandiri (Kecamatan Cariu) permusimnya dapat mencapai sekitar 2,5 ton, ke Gapoktan Cikutamahi (Kecamatan Cariu) sebanyak 6 ton, dan ke Gapoktan Sri Mukti (Kecamatan Jonggol) sebanyak 4 ton. Selain memasok benih dan pupuk, Gapoktan Subur Tani juga membeli beras organik setiap musimnya dari Gapoktan Pringgandani (Kecamatan Cariu) sebanyak 12 ton, sedangkan dari Gapoktan Sri Mukti (Kecamatan Jonggol) kadangkala setiap bulannya sebanyak 2,5 ton. Permintaan beras organik dari Gapoktan Subur Tani karena adanya mitra yang menginginkan beras organik tetapi anggotanya belum ada yang membudidayakan beras organik.

Mengacu pada kondisi diatas, setidaknya terdapat 4 (empat) hal yang menyebabkan belum efektifnya Gapoktan yang pada akhirnya berdampak pada keikutsertaan anggota kelompoktani pada Kegiatan Penguatan-LDPM, yaitu Pertama, Ketua Gapoktan dan pengurus belum memaksimalkan sumber daya manusia yang dimiliki terutama dalam hal membantu dalam memperluas jaringan pemasaran Gapoktan dalam rangka meningkatkan modal dan usaha dan juga kerjasama dengan Gapoktan lainnya. Kinerja Gapoktan selama ini lebih banyak dilaksanakan secara personal figur pemimpin ketua Gapoktan dan belum dilaksanakan secara kolektif.

Kedua, Ketua Gapoktan jarang melakukan sosialisasi kegiatan sehingga informasi kegiatan tidak seluruh anggota dapat menerima. Gapoktan yang dibentuk sebagai wadah kelembagaan petani untuk menampung aspirasi dan keinginan anggotanya namun tidak berjalan sebagaimana mestinya, bahkan pada akhirnya menimbulkan rendahnya partisipasi anggota dalam kegiatan di Gapoktan. Kondisi tersebut diperkuat oleh Syahyuti (2003) yang mengungkapkan bahwa meskipun kelembagaan sudah dibentuk, tetapi pembinaan dan sosialisasi yang dijalankan cenderung individual, yaitu hanya kepada pengurus.

Ketiga, partisipasi dan kekompakan anggota kelompoktani dalam kegiatan Penguatan-LDPM masih relatif rendah, ini tercermin dari minimnya tingkat kehadiran anggota dalam setiap rapat pada kegiatan Penguatan-LDPM yang merupakan dampak dari minimnya sosialisasi kegiatan itu sendiri. Keempat, minimnya sumber daya manusia yang ingin mengelola Gapoktan padahal usia Ketua Gapoktan yang sudah berusia diatas 60 tahun dan telah lebih dari 3 (tiga) kali periode memimpin Gapoktan. Keinginan regenerasi kepengurusan Gapoktan yang diinginkan langsung dari ketua Gapoktan belum direspon positif oleh seluruh anggota karena belum disosialisasikan secara luas, juga masih adanya kekuatiran dari Ketua Gapoktan kepada penggantinya terutama masalah pengelolaan dana.

\section{SIMPULAN}

Implementasi Kegiatan PenguatanLDPM di Kabupaten Bogor, belum sepenuhnya dilaksanakan secara optimal, hal ini ditandai dengan rendahnya tingkat partisipasi anggota Gapoktan baik pada tahap perencanaan, pelaksanaan, pemantauan dan evaluasi, dan pemanfaatan hasil. Faktor pendapatan paling berpengaruh positif secara langsung terhadap partisipasi anggota Gapoktan pada kegiatan Penguatan-LDPM dibandingkan faktor motivasi dan intensitas menerima sosialisasikegiatanyangjuga samasama berpengaruh positif secara langsung terhadap partisipasi anggota Gapoktan pada kegiatan Penguatan-LDPM. Di sisi lain, usia berperngaruh negatif secara langsung terhadap partisipasi anggota Gapoktan pada kegiatan Penguatan-LDPM. Adapun faktorfaktor yang tidak signifikan mempengaruhi partisipasi anggota Gapoktan pada Kegiatan 
Penguatan-LDPM sebagai berikut: peranan penyuluh, kepemimpinan Gapoktan, dan kepemimpinan Kelompoktani.

Studi empiris juga membuktikan bahwa usia berpengaruh negatif terhadap pendapatan anggota Gapoktan dan intensitas menerima sosialisasi kegiatan, serta intensitas menerima sosialisasi kegiatan berpengaruh positif terhadap pendapatan anggota Gapoktan. Sosialisasi kegiatan akan lebih efektif jika lebih banyak diberikan kepada anggota yang berusia di bawah 50 tahun yang kemudian akan berdampak pada peningkatan pendapatan dengan diiringi peran serta aktif anggota Gapoktan pada kegiatan Penguatan-LDPM. Bagi anggota Gapoktan yang sudah berusia di atas 50 tahun disarankan agar mengikuti programprogram yang cocok bagi mereka.

Partisipasi anggota Gapoktan pada Kegiatan Penguatan-LDPM berpengaruh positif secara signifikan terhadap efektivitas Gapoktan. Namun, dari aspek pengembangan lembaga Gapoktan belum sepenuhnya optimal, hal ini disebabkan karena jarangnya sosialisasi kegiatan sehingga informasi kegiatan tidak seluruh anggota dapat menerima, kinerja Gapoktan lebih banyak dilaksanakan dan dikelola berdasarkan figur Ketua Gapoktan bukan berdasarkan kerjasama kolektif yang dibangun atas dasar keterlibatan seluruh anggota, dan minimnya sumber daya manusia yang ingin mengelola Gapoktan yang terlihat dari kepemimpinan ketua Gapoktan sudah lebih dari 3 (tiga) periode memimpin Gapoktan.

Terdapat beberapa saran yang perlu menjadi perhatian khusus bagi tim teknis kabupaten, penyuluh, dan Pengurus Gapoktan, yaitu pertama, rendahnya tingkat partisipasi anggota Gapoktan pada kegiatan Penguatan-LDPM dapat ditingkatkan dengan memperbanyak sosialisasi kegiatan baik secara kualitas maupun kuantitas dengan sasaran diutamakan kepada anggota Gapoktan yang berusia muda. Kedua, kinerja Gapoktan yang selama ini lebih banyak karena figur ketua Gapoktan bukan berdasarkan kolektivitas, maka perlu adanya kesadaran berkelompok yang dimunculkan baik oleh pengurus Gapoktan/Kelompoktani dan penyuluh maupun dari anggota itu sendiri. Kehadiran Gapoktan diposisikan sebagai wadah untuk menampung aspirasi dan kebutuhan yang diperlukan oleh anggotanya, sehingga anggota dapat terlibat penuh dalam kegiatan di Gapoktan karena ada kebutuhan yang ingin dicapai. Ketiga, masa kepemimpinan Gapoktan yang telah lebih dari 3 periode seyogyanya perlu adanya perbaikan AD/ART Gapoktan tentang masa kepengurusan Gapoktan untuk dibatasi agar tidak terlalu lama dan adanya peremajaan kepengurusan. Pengurus yang terpilih adalah orang-orang yang dapat bebas kepentingan, dapat menimbulkan kesadaran berkelompok anggotanya, dan dapat mempersatukan serta mampu mengelola Gapoktan sebagai organisasi petani yang dapat menguntungkan anggotanya.

\section{DAFTAR PUSTAKA}

Anonim, 2007, Peraturan Menteri Pertanian Nomor: $\quad$ 273/Kpts/OT.160/4/2007 tertanggal 13 April 2007 tentang Pedoman Pembinaan Kelembagaan Petani, Jakarta: Departemen Pertanian.

Arfani, 1987, Faktor yang Mempengaruhi Tingkat Partisipasi Anggota Kelompok Tani dalam Menerapkan Panca Usaha Tanaman Padi Sawah, Tesis: Institut Pertanian Bogor.

Arifah, N, 2002, Faktor-Faktor yang Mempengaruhi Tingkat Partisipasi Petani dalam Program Sekolah Lapang Pengendalian Hama Terpadu (SLPHT) (Studi Kasus di Kelompoktani Subur Jaya, Desa Ciherang, Kecamatan Dramaga, Kabupaten Bogor, Jawa Barat), Skripsi: Institut Pertanian Bogor.

Badan Ketahanan Pangan, 2009, Pedoman Umum Kegiatan Penguatan Lembaga Distribusi Pangan Masyarakat (LDPM) Tahun 2009. Jakarta: Badan Ketahanan Pangan. 
Yudhi Harsatriadi Sandyatma --Partisipasi Anggota Kelompok Tani dalam Menunjang Efektivitas Gapoktan pada Kegiatan Penguatan Lembaga Distribusi Pangan Masyarakat di Kabupaten Bogor

Daniel, M. D, Nieldalina, 2006, PRA (Participatory Rural Appraisal) Pendekatan Efektif Mendukung Penerapan Penyuluhan Partisipatif dalam Upaya Percepatan Pembangunan Pertanian. Jakarta: PT Bumi Aksara.

Hamidjoyo, S., 1991, Keterlibatan Wanita Dalam Sistem Usaha Tani Berkonservasi Selani Das Brantas Kabupaten Malang, Malang: Yayasan Pengembangan Desa.

Hariadi, S. S., 2011, Dinamika Kelompok: Teori dan Aplikasinya untuk Analisis Keberhasilan Kelompok Tani Sebagai Unit Belajar, Kerjasama, Produksi, dan Bisnis, Yogyakarta: Sekolah Pascasarjana Universitas Gadjah Mada.

Husodo, S., 2006. "Partisipasi Petani dalam Kegiatan DAFEP di Kabupaten Bantul", Jurnal Ilmu-Ilmu Pertanian, Vol 2, No. 1.

Kementerian Pertanian, 2011, Laporan Penguatan-LDPM, http://aplikasi. deptan.go.id/ smspldpm, diakses pada tanggal 17 Februari 2012.

Mardikanto, T., 2007, Sistem Penyuluhan Pertanian, Surakarta: Sebelas Maret University Press.

1987, Komunikasi Pembangunan, Surakarta: Sebelas Maret University Press.

Nazir, M, 2003, Metode Penelitian, Jakarta: Ghalia Indonesia.

Ndraha, T., 1990, Pembangunan Masyarakat Mempersiapkan Masyarakat Tinggal Landas, Jakarta: Rineka Cipta.

Pudjianto, K., 2009, Partisipasi Masyarakat dalam Rehabilitasi Hutan, Lahan dan Konservasi Sumberdaya Air di Sub DAS Keduang, Daerah Hulu DAS Bengawan Solo, Tesis: Institut
Pertanian Bogor.

Salim, A., 2006, Teori dan Paradigma Penelitian Sosial, Edisi Kedua, Yogyakarta: Tiara Wacana.

Satria, A.; Zulkarnaen, Iskandar; Noviana, Deni; Anggraini Eva, 2008, Pokok Pemikiran IPB: Pembangunan Pertanian dan Pedesaan Untuk Kesejahteraan Rakyat, Bogor: Institut Pertanian Bogor.

Soedijanto, 1996, Psikologi Belajar Mengajar, Jakarta: Universitas Terbuka.

Steers, R. M., 1985, Efektivitas Organisasi, Jakarta: Erlangga.

Swedianti, K., 2011, Partisipasi Masyarakat dalam Program Nasional Pemberdayaan Masyarakat Mandiri Perkotaan (PNPM), Skripsi: Institut Pertanian Bogor.

Syahyuti, 2003, Bedah Konsep Kelembagaan: Strategi Pengembangan dan Penerapannya dalam Penelitian Pertanian, Bogor: Pusat Penelitian dan Pengembangan Sosial Ekonomi Pertanian.

Tanjungsari Kurnia, 2010, Faktor-Faktor yang Mempengaruhi Partisipasi Petani Dalam Pengelolaan Tanaman Terpadu Padi di Kecamatan Sleman Kabupaten Sleman Provinsi Daerah Istimewa Yogyakarta, Skripsi: Universitas Gadjah Mada.

Tashakkori Abbas dan Teddlie Charles, 2010, Handbook of Mixed Methods in Social and Behavioral Research, Edisi Bahasa Indonesia, Yogyakarta:Pustaka Pelajar

Tjokroamidjojo,1996,PerencanaanPembangunan, Jakarta: Gunung Agung.

Umstot, D., 1988, Understanding Organizational Behaviour, New York: West Publishing Company. 